\title{
Editorial: All Straussians Now?
}

Of course, we are not all Straussians, even now, and not just because Leo Strauss is virtually unknown outside the small circle of his followers. (Leo Strauss's name does not even appear in the first five works of philosophical reference we consulted.) Ignorance aside, many readers of Philosophy, along with many other intellectuals, academics, teachers and students, would in any case be appalled to learn that they have any beliefs in common with what is known today as neo-Conservatism. But neo-Conservatism is undoubtedly influential in contemporary American foreign policy, and its philosophical roots are Straussian in the very direct sense that many of those driving that policy would regard themselves as having been influenced by Strauss. And only the other day we heard an eminent member of the Conservative Shadow Cabinet in Britain declare that modern conservatism had just two options: to go backwards with Michael Oakeshott's inimitable brand of clubbable nostalgia or brightly forward into the twenty-first century with the neoConservatism of Leo Strauss.

To describe Leo Strauss as a neo-Conservative is itself an irony Strauss may have been appreciated. For Strauss was neither neo nor a conservative. He was not neo because he believed that the only way to understand our situation was to go back to the ancients, and to understand them on their own terms. We had to read Plato and Aristotle, and to understand them we had to read the Greek historians, Xenophon above all; to understand modernity we had to read Machiavelli, the first modern, and to understand him we had to read Livy, and so on and so on. And he was not conservative, if by conservative one means having an over-weening commitment to some local history or tradition or being nostalgic for an imaginary past. Strauss believed, as did the ancients, in a universal human nature, and he believed that from this nature followed certain things about the conditions necessary for human flourishing, now and in the future.

Strauss was born in Germany in 1899, into orthodox Jewry. His studies in Germany included a year in Freibourg as a colleague of both Husserl and Heidegger. He left Germany in 1932, and for most of the rest of his life he was a teacher in American universities, notably in Chicago and St John's College Annapolis.

What the ancients and his own experience further taught Strauss was this: 'Liberal democracy is the only decent and just alternative doi:10.1017/S003181910400021X

(2004 The Royal Institute of Philosophy

Philosophy 792004 


\section{Editorial}

available to modern man. But he also knew that liberal democracy is exposed to, not to say beleagured by threats, both practical and theoretical. Among those threats is the aspect of modern philosophy that makes it impossible to give rational credence to the principles of the American regime, thereby eroding conviction of the justice of its cause.' The words are those of Allan Bloom, Strauss's pupil, taken from his obituary of Strauss in 1974, and in Strauss's view as well as in Bloom's the sources of that erosion included as well as Heidegger, Rousseau and Nietzsche.

Strauss himself had a horror of anything except thought. In Bloom's words he 'was active in no organization, served in no position of authority, and had no ambitions other than to understand and help others who might also be able to do so.'

Nevertheless, despite Strauss's own reticence and his almost complete neglect in the academic world, some of those he helped, and some of their pupils are now influential in the highest political circles in the USA. They too believe in a universal human nature and that it is to be found in Africa and Asia and everywhere else in the world, as much as in the West. They believe that if you have the power to afford the benefits of liberal democracy in places where people have for decades suffered under tyranny or are locked into cycles of ethnic strife and slaughter, you should not turn your head away and pass on the other side of the road, as in different ways old Conservatives and modern cultural relativists might be inclined to do. You should actually intervene, even at cost to yourself.

These beliefs may be wrong, but they could well seem attractive to those seeking a better future for the world as a whole. They are not self-evidently absurd or wicked. They, and their best sources, deserve thought and study. It is time for the writings of Leo Strauss to appear on syllabuses of political philosophy. 